\title{
CO-OPERATION-ITS NECESSITY AND COST
}

\author{
Br J. H. OLDHAM
}

I. THE PROBLEM

The World Missionary Conference at Edinburgh in 1910 was distinguished from all preceding conferences by the fact that it was not content to pass resolutions in favour of co-operation but created the machinery necessary to give effect to them by appointing a Continuation Committee which established a central office and appointed salaried officers. Following on this came the formation of the National Missionary Council in India and the China Continuation Committee, each with a definite programme of work involving a considerable budget.

These developments have created a new problem for the missionary societies. How are the new claims to be related to those of the work for which the societies are already responsible? The time seems to have come for the missionary societies in the light of the experience of the past eight years to face frankly this question and adopt a definite policy.

In its most concrete form the problem is one of finance. Ought the missionary societies to devote a proportion of their income to supporting these joint committees and their work, and if so to what extent and how ?

The Conference of Missionary Societies in Great Britain in 1918 approved of a budget of $£ 2825$ for the work of the joint committees in Great Britain, and this budget was met by contributions from the societies united in the Conference at the rate of 33s. for every $£ 1000$ of income. In addition to this a grant of $£ 200$ was made 
to the National Missionary Council in India and a similar grant to the China Continuation Committee, and these grants were contributed in the same way by the co-operating societies. The budget for the bodies concerned with missionary co-operation at home and abroad approved by the Foreign Missions Conference of North America in 1918 amounted to $\$ 70,539$. Only part of this was provided directly by the mission boards, the rest being contributed in special gifts.

The new claims are steadily growing. The joint committees both at home and in the mission field see before them new and larger tasks which there seems to be a clear call to undertake. They can do their work properly only if they are assured of the necessary funds. On the other hand the missionary societies have to weigh these new claims against those of the work for which they are already responsible, and the difficulty about the former is that when accepted they naturally become a first charge on the funds of the societies. When a body like the Conference of Missionary Societies or the China Continuation Committee has drawn up a budget, the individual missionary society is in the position of having to pay its proportionate contribution or to fall out of step with the other co-operating societies. Failure to keep step must lead in the end to the breakdown of co-operation. But the missionary societies will rightly regard the advantages of co-operation as involving too high a price if these can be obtained only by exposing the societies to uncontrolled and growing demands which must take precedence of all other claims on the funds at their disposal. The situation is plainly one which calls for clear thinking and a definite policy.

This paper is written with conditions in Great Britain especially in view, though it is hoped that the discussion may have a wider interest. A plan for missionary cooperation going far beyond anything suggested in the present article is under consideration in America. 


\section{THE NEED FOR COMMON ACTION}

The fundamental question to be decided is whether in present conditions there is a clear necessity for the missionary societies to set up joint committees to undertake certain work involving substantial expenditure. It might seem as if this question had already received an answer, since the missionary societies are as a matter of fact maintaining such committees at a considerable cost. But what is being done at present is still more or less in the experimental stage. No clear view has been reached as to the amount of expenditure which these new undertakings are likely to involve. The new claims have to gain a hearing among a multitude of existing claims which far exceed the income available to meet them. There is not yet a definite policy which has won general acceptance by the missionary societies.

The proposition to be established is that in order to achieve the objects for which missionary societies exist common action for certain purposes is just as necessary as the work which each society is carrying on independently. If the proposition is to win general acceptance it must be shown that there exist in the real world conditions which can be met by common action and in no other way.

There is nothing strange in the necessity for finding a place in the missionary programme for new developments. The missionary movement since its early beginnings has grown and expanded in many directions. At first the only missionaries sent out were men. But experience showed that women's work for women was equally necessary, and this discovery resulted in the growth of the women's missionary organizations which are now recognized to be an indispensable part of successful missionary effort. Some time elapsed before medical missions established themselves as a means of manifesting the gospel of love and became, as they are now, an integral part of the missionary movement. The genius of Alexand er Duff recognized that 


\section{I76 International Review of Missions}

it was not enough to detach individuals from the nonChristian systems of belicf and that it was necessary to undermine the strength of these systems themselves by the disintegrating force of truth, and he and his colleagues laid the foundations of those higher institutions of Christian learning which have done so much to spread a knowledge of Christianity in non-Christian lands. The history of missions has thus been full of fresh developments. It could not be otherwise, since to live is to grow. It is only natural that the changing conditions of the living world should from time to time call for new adaptations in missionary organization.

Are there then conditions in the world to-day which make a fresh development in missionary policy imperative? Before giving a more specific answer to this question, it may be well to call attention to a general change, of which missionary policy has perhaps not yet taken sufficient account-a change which is slowly but fundamentally transforming the conditions of human life. This change has been forcibly described by President Wilson in the following words :

Yesterday, and ever since history began, men were related to one another as individuals. . . . In the ordinary concerns of life, in the ordinary work, in the daily round, men dealt freely and directly with one another. To-day the everyday relationships of men are largely with great impersonal concerns, with organizations, not with other individual men. Now this is nothing short of a new social age, a new era of human relationships, a new stagesetting for the drama of life.

Missionary societies can no more be indifferent to a farreaching change of this kind than they can ignore other hard facts in the actual world, such as the existence of different languages. The wide movements and organized forces to which President Wilson refers affect the individual men and women whom we desire to win to faith in Christ. They determine the conditions under which missionary work is done, furthering or hindering it. When we speak of evangelizing the whole world we are apt to consider it 
merely geographically. But we must think of the whole intensively as well as extensively. Complete evangelization means not only reaching every individual, but the bringing of the whole life of each individual and not merely a part of it under the influence of Christ. The large and powerful forces which are daily moulding the lives of men cannot be left outside the purview of Christian missions.

With this thought in our minds we may now turn to consider three groups of facts intimately related to the progress and success of missions and giving rise to problems of which a successful solution can be found only by common consultation and united action on the part of the missionary societies.

\section{(1) Missions and Goternments}

The reports presented to the Edinburgh Conference included, as will be remembered, one on Missions and Governments. Since that report was written a number of large issues affecting the relations of missions and governments have arisen which were not contemplated or dealt with in the report. These are in part connected with the war but some are due to causes of a more permanent character. There are powerful influences pressing governments towards a policy of increasing restriction of missionary freedom.

The war has confronted governments with the difficulties involved in the conduct of missionary work by subjects of enemy powers. The British government has found it necessary to exclude for a period to be defined hereafter missionaries of enemy nationality from India and other parts of the British empire, and it may be assumed that a similar policy will be adopted by certain other governments. Inevitable as this policy may be in present circumstances, it creates a situation which needs to be carefully watched. In normal conditions of the world the principle which should prevail is that Christians should be free to obey their Lord's command to proclaim the Gospel to 
every creature, and the right to carry on disinterested missionary and philanthropic effort ought to be recognized, as was done by the Powers in the General Act of the Conference of Berlin in 1885 'without distinction of creed or nation.' Any limitation of the universality of this principle is beset with dangers. Restrictions which are imposed as a temporary measure for good anci adequate reasons may open the door to further restrictions imposed for reasons that are less adequate and good. The question is one that needs to be carefully watched in the missionary interest. It is all the more important because not only the work of missionaries of enemy nationality but also that of missionaries of a different nationality from that of the governing power may under certain circumstances seem to call for government regulation. To entrust any considerable share in the work of education to missionaries of alien nationality who may not fully understand or sympathize with the educational aims of the government may, from the government standpoint, present difficultics. It may be urged with truth that the disinterested co-operation of missionaries of other nationalities in the work of education may be a stimulating and valuable influcnce, introducing freshness of outlook and new and richer points of view. But this argument finds less ready acceptance in a world distracted by the anxieties and suspicions generated by war. The important matter to which the missionary societies need to give attention is that any restriction on the freedom of Christians to obey their Lord's command is a serious matter, and that the war has created a new situation which calls for earnest consideration and watchfulness.

A second influence affecting the policy of governments is the spread of Bolshevist and other ideas which are a menace to established law and order. Governments are being forced to pay increased attention to propaganda and realize the necessity of watching and in certain circumstances regulating it. It may seem a sufficient answer 
to any attempt to control missionary propaganda to say, in the words of the treaty between China and the United States, that 'the principles of the Christian religion are recognized as teaching men to do good and to do to others as they would have others do to them,' and that the effect of Christian teaching must be to make better and not worse citizens. But governments may point in reply to the activities of certain extreme and irresponsible bodies that claim $t_{i}$ be engaged in missionary work and to difficulties which arise where education is largely in the hano's of native teachers whose training and experience are necessarily limited. Attention was directed to these factors in the report of the Commission on the Native Rising in Nyassaland and similar ideas seem to have inspired a recent educational ordinance in Northern Rhodesia. It may be admitted that conditions may arise which call for regulation. But such regulation may go beyond what the circumstances require and, as in the Rhodesian ordinance referred to, may be of a character which seriously hampers Christian missions in their legitimate activities.

A third influence on government policy is the spirit of nationalism. The awakening of the national consciousness of peoples expresses itself among other ways in the desire to defend their institutions and their ancestral heritage against the inrush of western civilization. This may result in an attempt to restrict the propagation of Christianity as an alien influence threatening the integrity of the national life. The proposed transfer of certain branches of administration in India to popular control may be expected to present new and difficult problems for Christian missions more particularly in the sphere of education.

Even European governments may sometimes look on Christian propaganda as a disturbing influence in the social order, making the task of government more difficult. For example, the late lieutenant-governor of the northern provinces of Nigeria, Mr C. L. Temple, writes in a volume 
representing British administration at its best, and inspired by the fullest sympathy with native interests :

I venture to prophesy that if the policy of preserving the native institutions gains ground, the missionary bodies will find that the government will be forced, reluctantly enough but in the best interests of the natives, to restrict the sphere of their activities to an increasing extent, at all events for a time. ${ }^{1}$

As a result of these and, it may be, other causes recent years have witnessed a growing restriction of missionary freedom and many fresh regulations limiting opportunities which Christian missions have enjoyed in the past. Among other illustrations may be cited the Japanese regulations in Korea prohibiting all religious teaching and religious ceremonies in schools; the new policy of the British government in regard to missionaries of alien nationality; the proposal in India to introduce a conscience clause; the educational ordinance in Rhodesia to which reference has been made and similar tendencies in other African colonies; and the probability that the Berlin Act of 1885, to which missionaries in the Belgian and Portuguese Congo as well as in other parts of the continent have frequently had to appeal in defence of their liberties, will be replaced by some new international instrument in regard to which there is as yet no guarantee that it will contain an equally clear recognition of missionary freedom. To these and other particular illustrations which might be given must be added the general consideration that important new developments are taking place throughout Asia and Africa in government educational systems and policies, and that

1 It is only fair to Mr Temple to note that he goes on to say that if missions would adopt a policy which would obviate what he rcgards as the disastrous social consequences of their teaching he would be prepared to wilcome them :

' If it were recognized by them that before he can become a good Christian a native must become a good citizen, and that to enable him to become a good citizen he must acquire pride of race, patriotism and discipline, and that he can acquire these things only by our securing to him opportunities for development on his own racial and tribal lines and not on our, to him foreign and unnatural, lines of development, and the missionary bodies thus become a bulwark in place of a danger to the native administrations, then the whole position would be altered.' 
the effect of these new developments on Christian schools and colleges calls for earnest and continued attention.

If governments are adopting new policies, there is only one way of meeting these. The missionary societies must have a policy of their own. They must think out clearly what it is just and right to claim in regard to religious toleration and freedom of conscience and reasonable opportunity for missionary work. The policy must be based on principles that are capable of universal application. The policy will naturally have to be adapted to different conditions, but its fundamental principles must be the same. It will not do for missions to advocate the adoption of a certain policy in one country and to support principles inconsistent with it in another. Further, the policy must be a reasonable one, taking into account real difficulties with which governments may have to deal. Experience has shown that when the missionary societies present a reasonable policy and put it forward in the proper way, governments are willing to give it sympathetic consideration. Finally, the policy must be a united one. If missionary opinion is divided, the government will adopt its own policy and that will be an end of the matter. But if missions are to have a united policy the only way they can arrive at it is by appointing joint committees to consult and act for them.

To have a policy, however, is not enough. In relations with governments, as in all human affairs, there is a personal side. The foundation of good relations is mutual confidence. To succeed in negotiations with governments it is essential that missions should be represented by a body of men who have learned from growing experience the conditions with which they have to deal. This emphasizes the need for permanent committees, and where the questions to be dealt with are numerous or difficult the committees will require officers devoting a part or the whole of their time to the work. These committees are equally needed at home and in the mission field. 
The missionary societies seem to be faced with a clear alternative. They may leave matters to take their course, and in doing so incur a grave risk of finding their work seriously hampered and restricted as a result of the powerful forces operating in that direction. Or they may set up machinery which will ensure that their just and reasonable claims are understood and considered. The issues at stake are so far-reaching, and affect missionary interests so deeply that for this purpose alone it would seem wise for the missionary societies to maintain joint committees at home and in the mission field and to provide from their funds whatever may be needed $f \subset r$ their effective work.

Before we leave the subject of missions and governments it is important to correct any impression that may have been given by what has been said that the only relations between missions and governments are those required for settling points of difference when these arise. The spheres of missions and governments are quite distinct. The kingdom which Christian missions seek to serve is not of this world. Their aims are religious and not political. But while the spheres of missions and governments are distinct, and it is essential that the distinction should always be kept clearly in view, there remains a large field which is of common interest to both. The general welfare of the people among whom they work is a deep concern of Christian missions. Our Lord healed the bodies as well as the souls of men. His concern was with the whole man, and His followers have learned from Him to care for everything that makes for the true health of those to whom they offer His salvation. Governments in so far as they are animated by the Christian spirit or by humanitarian motives are likewise concerned to promote the welfare of those over whom they bear rule. The governments of Asia and Africa are facing an overwhelming task in seeking to promote the material well-being of the populations under their rule and to lead them forward to the full 
development of their manhood and womanhood. In the carrying out of this task there is a large field for the sympathetic co-operation of missions with governments. It is a task in which Christian missions have a direct interest and to the fulfilment of which they have their own special contribution to make. Much may be gained through the appointment of joint committees who can take a broad view of the social forces which affect the lives of Asiatic and African peoples and help to relate missionary policy with what is best and most progressive in the policy of govei nments.

\section{(2) Larger Tasks in the Mission Field}

Christian missions have to take account not only of political factors but equally of the social forces which are shaping the lives of the people among whom they work. Take, for example, the present position in regard to Christian education. In Asia missions have in the past had a considerable share, and in Africa the predominant share, in the work of education. But everywhere governments are increasingly taking control of education and it is impossible for voluntary effort to compete with the much ampler resources of the state. The missionary share in education in proportion to that of the state and of other bodies must inevitably diminish from year to year. Does this mean that the great days of missionary education are already in the past? Quantitatively there appears to be no escape from this conclusion. There is only one way in which Christian schools can retain their influence in face of the changes which are everywhere in progress. It is that they should lay their whole emphasis on quality. By embodying the Christian ideal at its highest, and being content with nothing short of the best, they may set standards which will influence the whole development of education and furnish a conspicuous evidence of the character and power of Christ. They have 
done this in no small degree in the past. Clearly it is the only policy which offers any hope for the future.

In order to carry out this policy the missionary societies must consult together. Governments have an educational policy. The missionary societies, to achieve their own distinctive aims, must have a policy of their own, and it must be a common policy. They must stand for something definite and clearly understood in the educational life of the country. Further, certain tasks which they may want to undertake may prove too great for the resources of any one society. A united effort may be necessary to accomplish them.

Two illustrations may be given of what is meant. The first is the establishment of the Women's Christian College in Madras, which, maintained jointly by twelve different missionary societies, has a staff of seven of the best women that Great Britain and America have to give, and is thus in a position to exert a far-reaching influence on the education of Indian women. The second illustration is the commission which it is hoped will start within a few weeks to make a thorough study of the problems of village education in India, more especially in connexion with the needs of the mass movements. Both of these undertakings are of the first importance for the progress of Christianity in India. Yet it is very unlikely that either would have come to pass if there had not been in existence a joint committee on education able to take action in matters which were the concern not so much of any one missionary society as of all societies.

Large questions of a similar nature, affecting the work not of one society but of all, arise in connexion with medical missions. Is the true policy of medical missions to rely exclusively on the work of foreign doctors or to raise up a body of native Christian doctors? There can be no doubt that the latter policy will in the end yield the largest results. But as soon as we come to the question of training native doctors we are at once confronted with the need for a united policy and for co-operation. Medical education according to modern standards is very expensive. It is 
impossible for the missionary societies with their present resources to maintain more than a very few first-rate medical colleges. It is a doubtful question how much longer it is desirable, in some mission fields at any rate, to maintain any medical college that is not first rate. An institution that is manifestly inferior to a government institution close at hand is not a very effective means of commending the Christian gospel. It is sufficient to mention these points to show the necessity for common planning and for the uniting of missionary resources in a concentrated effort.

The same thing is true in regard to the provision of an adequate Christian literature. No branch of missionary effort more urgently needs to be strengthened. It is an unsound policy to educate pupils in the missionary schools and to leave them without any good literature to read. Equally little can we look for a strong church, if its ministry and laity are without books to feed their moral and spiritual life and enable them to attain to full Christian growth. An adequate Christian literature, however, can, as experience has shown, be provided only by united action. The subject is only now receiving the attention it deserves because joint committees acting on behalf of the missionary societies have been formed in Great Britain, America, Japan, China and India to deal with it.

Other illustrations might be added. What has been said, however, may suffice to show that certain things necessary for the complete realization of the aims of missionary societies are likely to be done only if joint committees are formed to survey the field as a whole and to provide the machinery for common action when it is needed. Such committees provide an opportunity of viewing the missionary situation from a different angle from that of the committees of a missionary society. Questions come before them which do not naturally find a place on the agenda of the committees of individual societies. The business which comes before each society is necessarily and rightly determined by the needs of its own missions. 
Its immediate and direct responsibility is to make the work of these missions as efficient as possible. It has no special call to think of tasks which might be attempted in co-operation with other societies, nor if it did would it have the means of forming a judgment since the other societies are not represented in its committees. Unless joint committees exist to attend to these matters there is a danger that they will not receive attention. What is everybody's business is apt to be nobody's business. It is true that not a little successful co-operation has taken place in the past without any central unifying body, but this has been due to individual initiative, which may or may not be forthcoming when it is needed, and the time has come to make regular provision for dealing with matters that can best be carried out in co-operation. The argument of this paper is that if in present conditions the Church is to rise to the full height of its missionary obligations and if the work of evangelization is to be completely carried out, joint committees are for certain purposes essential, and provision must therefore be made for them.

(3) The Presentation of the Missionary Appeal to. The Home Church

Attention may be drawn, lastly, to conditions affecting the presentation of the missionary cause to the home Church. One of the great problems before missionary societies at the present time is to bring home the missionary appeal to the younger generation of men and women who in the past few years have responded so nobly to the call of national service. A whole new generation has to be won to a belief in the missionary cause. How amid the throng of interests which engross them can the call of Christian missions find an entrance to their minds and win a hold upon their hearts ? We cannot, indeed, expect Christian missions to be supported by those who have themselves no personal faith in Christ. But there are 
many who if they could be got to understand would be hearty supporters of missionary work. Their indifference is due to absorption in other things or to prejudice. They never come to a missionary meeting or read a missionary book or magazine. If they are to be won, new means must be found of reaching them.

A story is told of Marshal Foch that during a severe battle a message was brought to him from some hardpressed division that it could no longer hold on, and that his comment on receiving the news was, 'I cannot hold on ; well then, I attack.' The story is significant for the present missionary situation. The missionary cause is passing through a critical period. It will not be easy to hold on. Safety seems to lie in a daring advance. There must be a bolder, stronger presentation of the missionary appeal. A new attempt must be made to show the relation of Christian missions to the vital problems of the world today. The missionary cause must strike its roots deeper into the national life. This will involve a far larger and more effective use of the press. Its columns will be open for living missionary matter if it is presented in language understood by the ordinary man. There is equal need for a new, larger, more varied and more popular missionary literature. If the missionary cause is not to lose ground, our task is to convince the best mind of the nation that Christian missions have a vital relation to the real problems of the world to-day. This is the task of our common Christianity, calling for all the gifts and resources of the Christian Church. The work can be done effectively only through co-operation.

\section{THE FINANCE OF CO-OPERATION}

The fundamental question is whether under present conditions joint committees at home and in the mission field are for certain purposes essential. It is one about which the missionary societies must definitely make up their minds. If joint committees are needed they must be provided with the funds necessary to do efficient work. The 
only reason for appointing them at all is that they are required to deal with matters of great importance, and funds are just as necessary for their effective work as for the efficient carrying on of the rest of the work undertaken by missionary societies. The results achieved here as elsewhere will correspond with the time and strength and resources given to the task in hand.

The question then arises how the funds required should be provided. There appear to be three ways in which this may be done. The first is by direct contributions from the missionary societies on a proportionate basis. The second is by gifts from individuals. The third is by a combination of the two foregoing methods.

There are two strong reasons in favour of the funds being provided at least in part by contributions from the missionary societies. The first, if the argument of the present paper is sound, is that the objects for which these joint committees are required are essential to the complete fulfilment of the purposes for which the missionary socicties exist. Their work is just as much the proper work of the missionary societies as that for which each society has sole responsibility. The second reason is that if the work of the joint committees is supported by the missionary societies it will also be under their control. What is wanted to meet the needs of the mission field at the present time is not an independent organization auxiliary to the missionary societies, but united action by the societies themselves to rcalize their common aims. For these reasons it seems desirable that the work done in co-operation should in the main depend on direct contributions from the missionary societies.

On the other hand, as has already been pointed out, it is impossible for the missionary societies to put themselves in a position in which they become liable for meeting uncontrolled and growing demands which must, from the nature of the case, be a first charge on the funds at their disposal. A way out of the difficulty may be found by 
distinguishing between, on the one hand, the cost of maintaining joint committees at home and in the mission field for consultative purposes, and offices, salaried officers and staff in so far as these may be required, and, on the other hand, special undertakings, e.g. in education, medical missions or the provision of Christian literature, promoted by these committees and calling for united action and support. The expenditure needed for the first of these purposes is not liable to any large expansion. The demands under the second head may grow indefinitely. It ought not to be difficult to arrive at an estimate as to the amount which may be required in the immediate future to maintain in efficiency the joint committees that are at present required at home and abroad. It may be that an annual contribution of one quarter per cent of their income from the missionary societies would suffice to meet all reasonable requirements for a period of years to come. If the missionary societies are convinced that the existence of these joint committees is essential for the effective carrying on of the work of evangelization, it is right that, just as in the past they have taken medical missions and women's work into their programme they should, as a deliberate act of policy, agree to meet an approved budget for the work of these committees up to the amount of one quarter per cent of their income or whatever other amount may after consultation seem proper. Five shillings out of every $£ 100$ of income or one dollar in every $\$ 400$ does not seem an excessive amount to pay for the important ends to be gained thróugh such committees. An arrangement of this kind, while providing for the objects which can be secured only through co-operation would relieve the missionary societies from the fear of unlimited demands that might conflict with obligations to which they are already committed. While this arrangement would form the financial basis of missionary co-operation, it would be clearly understood that any fresh developments of the work of the joint committees would have to be financed in other ways. 
These fresh developments will undoubtedly come, and if they are necessary for the good of the missionary cause the funds to carry them forward ought to be provided. This can be done in two ways. Granted that it can be shown that a particular form of missionary service can be better rendered by the united action of several missionary societies than by the efforts of any one of them alone, there is no reason why missionary societies should not apportion some of the funds at their disposal for this perpose. They will be quite ready to do so if they are convinced that it will best further the cause that they have at heart. If therefore the joint committees at home or abroad see a particular work which they believe it would be of great advantage to the missionary cause to undertake, there can be no objection to their bringing the facts to the attention of the missionary societies and asking them whether they are prepared to contribute to its accomplishment. The important point is that the decision in response to such a request should be entirely voluntary, and that no society should be made to feel that if it should find it impossible, consistently with other claims upon its resources, to join in the undertaking it is failing to keep step with the other societies. If it is clearly understood that beyond a fixed amount determined by mutual agreement, the question whether a society should participate in a joint undertaking is in each instance entirely a matter for its own decision, there is no reason why societies, provided they are convinced that they can accomplish more by combined effort than by separate action, should not devote an increasing proportion of their resources to joint undertakings.

This is one way in which new developments arising out of the work of joint committees may be provided for. But there may arise developments which cannot be dealt with in this way. To gain the intelligent and convinced support of a large number of separate committees for a particular effort is a slow process. Funds may be needed more quickly to meet an urgent need. Occasions may also 
arise where a new effort, perhaps of an experimental kind, seems needed, the results of which are not sufficiently certain to justify the missionary societies in making a grant from their ordinary funds. To meet such needs as these the joint committees might be allowed to solicit special donations from individuals. Appeals of this kind would need to be carefully controlled and watched. It would be necessary to ensure that they should not encroach on the regular sources of the income of the missionary societies and that repeated appeals for special gifts are not made to those who are alraady contributing to their own missionary societies up to the measure of their ability. But if such appeals were controlled by such bodies as the Standing Committee of the Conference of Missionary Societies in Great Britain and Ireland and the Committee of Reference and Counsel in America, which are composed of representatives of the leading missionary societies, the dangers referred to would be guarded against and this particular kind of appeal might be found to be a means of interesting a number of people not yet contributing to missionary work as they ought and so enlarging the constituency of missionary supporters.

It is suggested that a sound policy designed to meet those needs of the mission field which can best be met by co-operation would have in view three distinct sources of income: (1) a fixed amount contributed by all societies on a proportionate basis sufficient to maintain in efficient working the joint committees required at home and in the mission field with their necessary staff ; (2) such further contributions as the missionary societies nay from tinue to time make for the support of undertakings in which they find it of advantage to co-operate with other missionary societies; and (3) individual gifts to funds of which the ultimate control would be in the hands of such bodies as the Conference of Missionary Socicties in Great Britain and the Foreign Missions Conference of North America. For the support of joint committees in the mission field a fourth source of income should be kept in view, though its growth 
may be slow, namely, income derived from local sources. The provincial Representative Councils of Missions in India derive their income from contributions by the missions working in the area, and the National Missionary Council in India and the China Continuation Committee may be expected to develop in the course of time local sources of income and to obtain increasing support from Indian and Chinese Christians.

The extent to which reliance should be placed on each of these sources of income is a matter of detail regarding which it should be easy after consultation to reach an agreement. The fundamental question to be decided is whether the time has come for missionary societies deliberately and definitely to include the work which can best, or only, be done by joint committees as an essential part of their programme, as they have in the past successively found a place for fresh activities to which the expansion of their work has led. Recognition has already been given to missionary co-operation in practice. What is needed is that it should be placed on a more secure basis and that there should be a clearer understanding of what the policy involves. If missionary co-operation thus becomes a clearly recognized element in the policy of missionary societies it may be found that even larger gains have come to us than the particular services rendered by the joint committees at home and abroad. Among these will be a perhaps insensible yet real widening of outlook and enrichment of experience through contact with others; a new strength growing out of fellowship; a vitalizing of the whole missionary cause through the realization and the manifestation to the home Church and to the non-Christian world of a real community of aim and purpose in spite of differences which are recognized to be real ; and the hastening through multiplied opportunities of intercourse of the day when differences will be transcended and the unity of those who are Christ's will find full and perfect expression. 